GEOLOGICAL SURVEY CIRCULAR 709

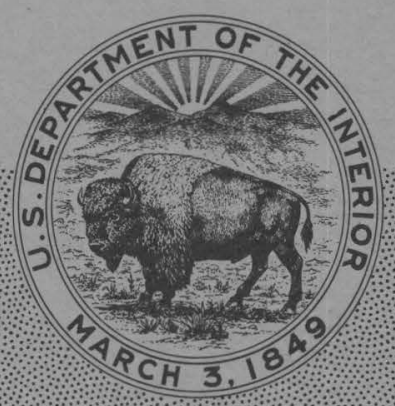

Bibliography and Index of

U.S. Geological Survey

Publications Relating to

Coal, January 1971-June 1974 

Bibliography and Index of

U.S. Geological Survey

Publications Relating to

Coal, January 1971-June 1974

By Flora K. Walker

GEOLOGICAL SURVEY CIRCULAR 709

A supplement to

Geological Survey Bulletin 1377 
United States Department of the Interior

ROGERS C. B. MORTON, Secretary

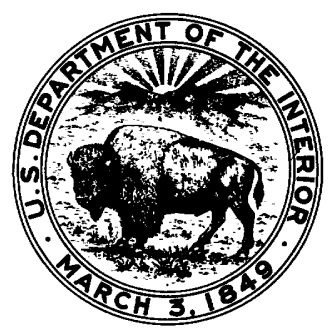

Geological Survey

V. E. McKelvey, Director 


\section{PREFACE}

This bibliography and index contains about 200 reports and maps relating to coal published by the U.S. Geological Survey in the $3 \frac{1}{2} 2$-year period, January 1971 through June 1974. It is supplementary to Geological Survey Bulletin 1377 titled "Bibliography and Index of U.S. Geological Survey Publications Relating to Coal, 1882-1970."

The availability and price of reports and maps cited in this supplementary bibliography are given in the pamphlets and leaflets listed below:

1. A pamphlet titled "Publications of the Geological Survey," which is published annually.

2. A leaflet titled "New Publications of the Geological Survey," which is published monthly.

3. A circular titled "Reports and maps of the Geological Survey released only in the open files," which was published annually through 1973 and for early 1974. (Since May 1974 open-file reports and maps have been listed in the monthly "New Publications of the Geological Survey.")

These lists must be consulted to obtain information necessary to order a report. Copies of these lists are available free upon request addressed to the U.S. Geological Survey, Reston, Virginia 22092.

Most of the publications cited in this bibliography may be consulted in large public libraries and in most college and university libraries. A selected list of such libraries is given in Geological Survey Bulletin 1377, p. 161-173. 



\section{CONTENTS}

Preface -

Bibliography -- - - -

Notes and additions _.

Index 



\title{
Bibliography and Index of U.S. Geological Survey Publications Relating to Coal January 1971-June 1974
}

\author{
By Flora K. Walker

\section{BIBLIOGRAPHY}

Albee, H. F., 1972, Preliminary geologic map of the Observation Peak quadrangle, Teton and Lincoln Counties, Wyoming: U.S. Geol. Survey open-file map, scale 1:24,000.

Alvord, D. C., 1971, Geologic map of the Hellier quadrangle, Kentucky-Virginia, and part of the Clintwood quadrangle, Pike County, Kentucky: U.S. Geol. Survey Geol. Quad. Map GQ-950, scale 1:24,000.

Alvord, D. C., and Miller, R. L., 1972, Geologic map of the Elkhorn City quadrangle, Kentucky-Virginia, and part of the Harman quadrangle, Pike County, Kentucky: U.S. Geol. Survey Geol. Quad. Map GQ-951, scale 1:24,000.

Arndt, H. H., 1971a, Geologic map of the Ashland quadrangle, Columbia and Schuylkill Counties, Pennsylvania: U.S. Geol. Survey Geol. Quad. Map GQ-918, scale 1:24,000.

$1971 \mathrm{~b}$, Geologic map of the Mount Carmel quadrangle, Columbia, Northumberland, and Schuylkill Counties, Pennsylvania: U.S. Geol. Survey Geol. Quad. Map GQ-919, scale 1:24,000.

Arndt, H. H., Wood, G. H., Jr., and Schryver, R. F., 1973, Geologic map of the south half of the Shamokin quadrangle, Northumberland and Columbia Counties, Pennsylvania: U.S. Geol. Survey Misc. Geol. Inv. Map I734, scale 1:24,000 [1974].

Averitt, Paul, 1973, Coal, in United States mineral resources (Brobst, D. A., and Pratt, W. P., eds.): U.S. Geol. Survey Prof. Paper 820, p. 133-142, 3 figs., 3 tables.

Averitt, Paul, Breger, I. A., Swanson, V. E., Zubovic, Peter, and Gluskoter, H. J., 1972, Minor elements in coal-a selected bibliography, in Geological Survey research 1972: U.S. Geol. Survey Prof. Paper 800-D, p. D169-D171.

Averitt, Paul, and Lopez, Lorreda, 1972, Bibliography and index of U.S. Geological Survey publications relating to coal, 1882-1970: U.S. Geol. Survey Bull. 1377, 173 p.

Ball, T. E., 1973, Map showing bedrock topography and subcrop of a selected bed beneath alluvial deposits of part of the Henderson quadrangle, Henderson County, Kentucky: U.S. Geol. Survey Misc. Geol. Inv. Map I-812, scale 1:24,000.

Barclay, C. S. V., 1971, Preliminary geologic map of the Dengate quadrangle, Morton County, North Dakota: U.S. Geol. Survey open-file rept., geologic map, scale 1:24,000, 2 sheets stratigraphic sections, text.
1973, Geologic map and lignite deposits of the Glen Ullin quadrangle, Morton County, North Dakota: U.S. Geol. Survey Coal Inv. Map C-54, scale 1:24,000.

Barnum, B. E., 1974, Preliminary geologic map and coal resources of the Ranchester quadrangle, Sheridan County, Wyoming, and Big Horn County, Montana: U.S. Geol. Survey open-file rept. 74-35, 4 p., 2 sheets, geologic map, scale 1:24,000, coal sections.

Bergin, M. J., 1973, Bedrock geologic map of the anthracitebearing strata in the northwestern part of the Wilkes-Barre East quadrangle, Pennsylvania: U.S. Geol. Survey Misc. Geol. Inv. Map I-753, scale 1:12,000 [1974].

Berryhill, H. L., Jr., Schweinfurth, S. P., and Kent, B. H., 1971, Coal-bearing Upper Pennsylvanian and Lower Permian rocks, Washington area, Pennsylvania; Part 1. Lithofacies; Part 2. Economic and engineering geology: U.S. Geol. Survey Prof. Paper 621, 47 p., plates.

Bowers, W. E., 1972, Preliminary geologic map and coal resources of the Pine Lake quadrangle, Garfield County, Utah: U.S. Geol. Survey open-file rept., geologic map, scale 1:24,000, 1 sheet columnar section, 1 sheet graphic coal sections.

1973a, Geologic map and coal resources of the Upper Valley quadrangle, Garfield County, Utah: U.S. Geol. Survey Coal Inv. Map C-60, 2 sheets, geologic map, scale 1:24,000, coal sections [1974]. [Supersedes open-file rept. of 1968.]

1973b, Geologic map and coal resources of the Griffin Point quadrangle, Garfield County, Utah: U.S. Geol. Survey Coal Inv. Map C-61, 2 sheets, geologic map, scale 1:24,000, coal sections [1974].

1974, Preliminary geologic map and coal resources of the Henrieville quadrangle, Garfield and Kane Counties, Utah: U.S. Geol. Survey open-file rept., 2 sheets, scale 1:24,000.

Briggs, R. P., 1973, Guide to selected large-scale geologic maps of southwestern Pennsylvania (west of $78^{\circ} 45^{\prime}$ meridian and south of $41^{\circ} 15^{\prime}$ parallel): U.S. Geol. Survey open-file rept., 26 p., 2 figs.

Bryson, R. P., and Bass, N. W., 1973, Geology of Moorhead coal field, Powder River, Big Horn, and Rosebud Counties, 
Montana: U.S. Geol. Survey Bull. 1338, 116 p., plates [1974].

Carlson, J. E., 1971, Geologic map of the Webbville quadrangle, eastern Kentucky: U.S. Geol. Survey Geol. Quad. Map GQ927, scale 1:24,000.

Cashion, W. B., 1973, Geologic and structure map of the Grand Junction quadrangle, Colorado and Utah: U.S. Geol. Survey Misc. Geol. Inv. Map I-736, scale 1:250,000.

Colton, R. B., and Lowrie, R. L., 1973, Map showing mined areas of the Boulder-Weld coal field, Colorado: U.S. Geol. Survey Misc. Field Studies Map MF-513, scale 1:48,000.

Csejtey, Bela, Jr., 1971, Geologic map of the Bledsoe quadrangle, southeastern Kentucky: U.S. Geol. Survey Geol. Quad. Map GQ-889, scale 1:24,000.

Cullins, H. L., 1971, Geologic map of the Rangely quadrangle, Rio Blanco County, Colorado: U.S. Geol. Survey Geol. Quad. Map GQ-903, scale 1:24,000.

DeLaney, A. O., and Englund, K. J., 1973, Geologic map of the Ault quadrangle, northeastern Kentucky: U.S. Geol. Survey Geol. Quad. Map GQ-1066, scale 1:24,000.

Denson, N. M., Keefer, W. R., and Horn, G. H., 1973, Coal resources of the Gillette area, Wyoming: U.S. Geol. Survey Misc. Geol. Inv. Map I-848-C, scale 1:125,000 [1974].

Dunrud, C. R., and Barnes, B. K., 1972, Engineering geologic map of the Geneva Mine area, Carbon and Emery Counties, Utah: U.S. Geol. Survey Misc. Geol. Inv. Map I-704, 2 sheets, scale $1: 6,000$.

Dunrud, C. R., Osterwald, F. W., and Hernandez, Jerome, 1973, Summary of the seismic activity and its relation to geology and mining in the Sunnyside mining district, Carbon and Emery Counties, Utah, during 1967-1970: U.S. Geol. Survey open-file rept., $86 \mathrm{p}$., $10 \mathrm{pl}$.

Englund, K. J., 1972a, Availability of low-sulfur coal in McDowell County, West Virginia: U.S. Geol. Survey openfile rept., 19 p., 3 figs.

1972b, Availability of low-sulfur coal in Mercer County, West Virginia: U.S. Geol. Survey open-file rept., 14 p., 3 figs.

1972c, Availability of low-sulfur coal in Raleigh County, West Virginia: U.S. Geol. Survey open-file rept., 23 p., 3 figs., 1 table.

1972d, Availability of low-sulfur coal in Wyoming County, West Virginia: U.S. Geol. Survey open-file rept., 22 p., 3 figs.

Englund, K. J., and Windolph, J. F., Jr., 1972, Availability of low-sulfur coal in Greenbrier County, West Virginia: U.S. Geol. Survey open-file rept., 21 p., 8 figs., 1 table.

Fairer, G. M., 1973a, Geologic map of the Robards quadrangle, Henderson and Webster Counties, Kentucky: U.S. Geol. Survey Geol. Quad. Map GQ-1084, scale 1:24,000.

$1973 \mathrm{~b}$, Geologic map of the Poole quadrangle, western Kentucky: U.S. Geol. Survey Geol. Quad. Map GQ-1088, scale $1: 24,000$.

Fairer, G. M., and Norris, R. L., 1972, Geologic map of the Curdsville quadrangle, western Kentucky: U.S. Geol. Survey Geol. Quad. Map GQ-1039, scale 1:24,000 [1973].

Fassett, J. E., and Hinds, J. S., 1971, Geology and fuel resources of the Fruitland Formation and Kirtland Shale of the San Juan Basin, New Mexico and Colorado: U.S. Geol. Survey Prof. Paper 676, 76 p., plates.

Franklin, G. J., 1973, Geologic map of the Millport quadrangle, Muhlenberg and Hopkins Counties, Kentucky: U.S. Geol. Survey Geol. Quad. Map GQ-1050, scale 1:24,000.
Froelich, A. J., 1972, Geologic map of the Wallins Creek quadrangle, Harlan and Bell Counties, Kentucky: U.S. Geol. Survey Geol. Quad. Map GQ-1016, scale 1:24,000.

1973a, Geologic map of the Louellen quadrangle, southeastern Kentucky: U.S. Geol. Survey Geol. Quad. Map GQ-1060, scale 1:24,000.

$1973 \mathrm{~b}$, Geologic map of the Pineville quadrangle, Bell and Knox Counties, Kentucky: U.S. Geol. Survey Geol. Quad. Map GQ-1129, scale 1:24,000 [1974].

Froelich, A. J., and McKay, E. J., 1972, Geologic map of the Harlan quadrangle, Harlan County, Kentucky: U.S. Geol. Survey Geol. Quad. Map GQ-1015, scale 1:24,000.

Froelich, A. J., and Stone, B. D., 1973, Geologic map of parts of the Benham and Appalachia quadrangles, Harlan and Letcher Counties, Kentucky: U.S. Geol. Survey Geol. Quad. Map GQ-1059, scale 1:24,000.

Froelich, A. J., and Tazelaar, J. F., 1973, Geologic map of the Balkan quadrangle, Bell and Harlan Counties, Kentucky: U.S. Geol. Survey Geol. Quad. Map GQ-1127, scale $1: 24,000$ [1974].

Gildersleeve, Benjamin, 1971, Geologic map of the Nolin Reservoir quadrangle, western Kentucky: U.S. Geol. Survey Geol. Quad. Map GQ-895, scale 1:24,000.

1972a, Geologic map of the Morgantown quadrangle, Butler and Warren Counties, Kentucky: U.S. Geol. Survey Geol. Quad. Map GQ-1040, scale 1:24,000 [1973].

1972b, Geologic map of the Flener quadrangle, Butler and Ohio Counties, Kentucky: U.S. Geol. Survey Geol. Quad. Map GQ-1049, scale 1:24,000 [1973].

Gill, J. R., 1974, Stratigraphic sections of the Mesaverde Group, Lewis Shale, Fox Hills Formation, and Medicine Bow Formation, Carbon County, Wyoming: U.S. Geol. Survey open-file rept., 4 sheets.

Goode, H. D., 1973a, Preliminary geologic map of the Bald Knoll quadrangle, Utah: U.S. Geol. Survey Misc. Field Studies Map MF-520, scale 1:24,000 [1974].

1973b, Preliminary geologic map of the Skutumpah Creek quadrangle, Utah: U.S. Geol. Survey Misc. Field Studies Map MF-521, scale 1:24,000 [1974].

Goudarzi, G. H., 1971, Geologic map of the Panther quadrangle, Daviess County, Kentucky: U.S. Geol. Survey Geol. Quad. Map GQ-866, scale 1:24,000.

Goudarzi, G. H., and Smith, A. E., 1971, Geologic map of part of the Owensboro West quadrangle, in Daviess County, Kentucky: U.S. Geol. Survey Geol. Quad. Map GQ-890, scale $1: 24,000$.

Grazis, S. L., 1974a, Preliminary geologic map and coal resources of the Scaper Reservoir quadrangle, Campbell County, Wyoming: U.S. Geol. Survey open-file rept., 2 sheets, geologic map, scale $1: 24,000$, coal sections.

1974b. Preliminary geologic map and coal resources of the Gap SW quadrangle, Campbell County, Wyoming: U.S. Geol. Survey open-file rept. 74-24, 2 sheets, geologic map, scale $1: 24,000$, coal sections.

$1974 c$, Preliminary geologic map and coal resources of the Pleasantdale quadrangle, Campbell County, Wyoming: U.S. Geol. Survey open-file rept. 74-25, 2 sheets, geologic map, scale 1:24,000, coal sections.

1974d, Preliminary geologic map and coal resources of the Kicken Creek quadrangle, Campbell County, Wyoming: U.S. Geol. Survey open-file rept. 74-26, 2 sheets, geologic map, scale 1:24,000, coal sections. 
Grubb, H. F., and Ryder, P. D., 1972, Effects of coal mining on the water resources of the Tradewater River basin, Kentucky: U.S. Geol. Survey Water-Supply Paper 1940, 83 p., plates in pocket [1973].

Gualtieri, J. L., 1973, Geologic map of the Sandgap quadrangle, Jackson County, Kentucky: U.S. Geol. Survey Geol. Quad. Map GQ-1100, scale 1:24,000 [1974].

Hackman, R. J., 1972, Maps showing extent and thickness of coal beds and amount of overburden on coal beds in the Salina quadrangle, Utah: U.S. Geol. Survey Misc. Geol. Inv. Map I-591-I, scale 1:250,000 [1973].

Hadley, D. G., 1972a, Availability of low-sulfur coal in Clay County, West Virginia: U.S. Geol. Survey open-file rept., 16 p., 4 figs., 1 table.

1972b, Availability of low-sulfur coal in Fayette County, West Virginia: U.S. Geol. Survey open-file rept., 20 p., 3 figs., 1 table.

1972c, Availability of low-sulfur coal in Kanawha County, West Virginia: U.S. Geol. Survey open-file rept., 18 p., 3 figs., 1 table.

1972d, Availability of low-sulfur coal in Nicholas County, West Virginia: U.S. Geol. Survey open-file rept., 16 p., 4 figs., 2 tables.

Hail, W. J., Jr., 1972a, Reconnaissance geologic map of the Cedaredge area, Delta County, Colorado: U.S. Geol. Survey Misc. Geol. Inv. Map I-697, scale 1:48,000.

1972b, Preliminary geologic map of the Barcus Creek SE quadrangle, Rio Blanco County, Colorado: U.S. Geol. Survey Misc. Field Studies Map MF-347, scale 1:24,000.

1974, Geologic map of Smizer Gulch quadrangle, Rio Blanco and Moffat Counties, Colorado: U.S. Geol. Survey Geol. Quad. Map GQ-1131, scale 1:24,000.

Haley, B. R., and Hendricks, T. A., 1971, Geology of the Van Buren and Lavaca quadrangles, Arkansas and Oklahoma: U.S. Geol. Survey Prof. Paper 657-A, p. A1-A41, plate.

Hansen, D. E., 1972, Geologic map of the Drakesboro quadrangle, Muhlenberg County, Kentucky: U.S. Geol. Survey Geol. Quad. Map GQ-934, scale 1:24,000.

1973, Geologic map of the Dawson Springs SW quadrangle, western Kentucky: U.S. Geol. Survey Geol. Quad. Map GQ-1061, scale 1:24,000.

Hayes, P. T., 1973, Preliminary geologic map of the Croton 1 SW quadrangle, Campbell County, Wyoming: U.S. Geol. Survey Misc. Field Studies Map MF-544, scale 1:24,000 [1974].

Haynes, D. D., Vogel, J. D., and Wyant, D. G., 1972, Geology, structure, and uranium deposits of the Cortez quadrangle, Colorado and Utah: U.S. Geol. Survey Misc. Geol. Inv. Map I-629, scale 1:250,000.

Hoge, H. P., and Chaplin, J. R., 1972, Geologic map of the Morehead quadrangle, Rowan County, Kentucky: U.S. Geol. Survey Geol. Quad. Map GQ-1022, scale 1:24,000.

Hosterman, J. W., 1972, Underclay deposits of Somerset and eastern Fayette Counties, Pennsylvania: U.S. Geol. Survey Bull. 1363, 17 p., plates.

Hylbert, D. K., and Philley, J. C., 1971, Geologic map of the Bangor quadrangle, east-central Kentucky: U.S. Geol. Survey Geol. Quad. Map GQ-947, scale 1:24,000.

Johnson, W. D., Jr., 1971a, Geologic map of the Horton quadrangle, Ohio County, Kentucky: U.S. Geol. Survey Geol. Quad. Map GQ-915, scale 1:24,000.

$1971 \mathrm{~b}$, Geologic map of the Rosine quadrangle, western
Kentucky: U.S. Geol. Survey Geol. Quad. Map GQ-928, scale 1:24,000.

1972a, Geologic map of the Reed quandrangle, KentuckyIndiana: U.S. Geol. Survey Geol. Quad. Map GQ-1038, scale 1:24,000.

$1972 \mathrm{~b}$, Geologic map of parts of the Newburgh and Yankeetown quadrangles, Henderson and Daviess Counties, Kentucky: U.S. Geol. Survey Geol. Quad. Map GQ. 1045 , scale $1: 24,000$.

1973a, Geologic map of part of the Henderson quadrangle, Henderson County, Kentucky: U.S. Geol. Survey Geol. Quad. Map GQ-1074, scale 1:24,000.

$1973 \mathrm{~b}$, Geologic map of the Delaware quadrangle, western Kentucky: U.S. Geol. Survey Geol. Quad. Map GQ-1087, scale 1:24,000.

1973c, Geologic map of the Spottsville quadrangle, Henderson County, Kentucky: U.S. Geol. Survey Geol. Quad. Map GQ-1090, scale 1:24,000.

1973d, Geologic map of part of the Evansville South quadrangle, Henderson County, Kentucky: U.S. Geol. Survey Geol. Quad. Map GQ-1089, scale 1:24,000 [1974].

Johnson, W. D., Jr., and Smith, A. E., 1972a, Geologic map of the Utica quadrangle, western Kentucky: U.S. Geol. Survey Geol. Quad. Map GQ-995, scale 1:24,000.

$1972 \mathrm{~b}$, Geologic map of the Glenville quadrangle, McLean and Daviess Counties, Kentucky: U.S. Geol. Survey Geol. Quad. Map GQ-1046, scale 1:24,000 [1973].

Keefer, W. R., and Schmidt, P. W., 1973, Energy resource map of the Powder River Basin, Wyoming and Montana: U.S. Geol. Survey Misc. Geol. Inv. Map I-847-A, scale 1:500,000 [1974].

Kehn, T. M., 1971, Geologic map of the Greenville quadrangle, Muhlenberg County, Kentucky: U.S. Geol. Survey Geol. Quad. Map GQ-907, scale 1:24,000.

1973, Sturgis Formation (Upper Pennsylvanian), a new map unit in the western Kentucky coal field: U.S. Geol. Survey Bull. 1394-B, 24 p.

1974, Geologic map of parts of the Dekoven and Saline Mines quadrangles, Crittenden and Union Counties, Kentucky: U.S. Geol. Survey Geol. Quad. Map GQ-1147, scale $1: 24,000$.

Kent, B. H., 1971, Geologic map of the Garards Fort quadrangle and part of the Osage quadrangle, Greene County, Pennsylvania: U.S. Geol. Survey Misc. Geol. Inv. Map I-663, scale $1: 24,000$.

1972, Geologic map of the Prosperity quadrangle, southwestern Pennsylvania: U.S. Geol. Survey Geol. Quad. Map GQ-1003, scale 1:24,000.

1973, Geologic map of parts of the Masontown and Morgantown North quadrangles, Greene County, Pennsylvania: U.S. Geol. Survey Misc. Geol. Inv. Map I-743, scale $1: 24,000$ [1974].

Kinney, D. M., 1970a, Preliminary geologic map of the Gould quadrangle, North Park, Jackson County, Colorado: U.S. Geol. Survey open-file map, 2 sheets, scale 1:48,000.

$1970 \mathrm{~b}$, Preliminary geologic map of the Rand quadrangle, North and Middle Parks, Jackson and Grand Counties, Colorado: U.S. Geol. Survey open-file map, 2 sheets, scale $1: 48,000$.

1971, Preliminary geologic map of the southwest third of Kings Canyon quadrangle, North Park, Jackson County, Colorado: U.S. Geol. Survey open-file map, scale 1:48,000. 
Kinney, D. M., and Hail, W. J., Jr., 1970a, Preliminary geologic map of the Hyannis Peak quadrangle, North and Middle Parks, Jackson and Grand Counties, Colorado: U.S. Geol. Survey open-file map, 2 sheets, scale 1:48,000.

$1970 \mathrm{~b}$, Preliminary geologic map of the Walden quadrangle, North Park, Jackson County, Colorado: U.S. Geol. Survey open-file map, 2 sheets, scale 1:48,000.

Kinney, D. M., Hail, W. J., Jr., Steven, T. A., and others, 1970, Preliminary geologic map of Cowdrey quadrangle, North Park, Jackson County, Colorado: U.S. Geol. Survey openfile map, 2 sheets, scale 1:48,000.

Kosanke, R. M., 1972, Palynological investigations in the Pennsylvanian of Kentucky - VII: U.S. Geol. Survey open-file rept., $41 \mathrm{p}$.

1973, Palynological studies of the coals of the Princess reserve district in northeastern Kentucky: U.S. Geol. Survey Prof. Paper 839, 22 p., 1 plate [1974].

Landis, E. R., and Cone, G. C., 1971, Coal reserves of Colorado tabulated by bed: U.S. Geol. Survey open-file rept., 3 p., 515 tables.

Landis, E. R., and Hayes, P. T., 1973, Preliminary geologic map of the Croton $1 \mathrm{SE}$ quadrangle, Campbell County, Wyoming: U.S. Geol. Survey open-file map, scale 1:24,000, 2 sheets.

Landis, E. R., Reinemund, J. A., Cone, G. C., Schlick, D. P., and Kebblish, W., 1973, Analyses of Pakistan coals: U.S. Geol. Survey open-file rept., 71 p., 1 fig., 1 table.

Law, B. E., 1974, Preliminary geologic map and coal resources of the Fortin Draw quadrangle, Campbell County, Wyoming: U.S. Geol. Survey open-file rept. 74-36, 2 sheets, geologic map, scale 1:24,000, coal sections.

Law, B. E., and Grazis, S. L., 1972, Preliminary geologic map and coal resources of the Decker quadrangle, Big Horn County, Montana: U.S. Geol. Survey open-file rept., 1 map, scale $1: 24,000,1$ sheet graphic stratigraphic sections, 1 sheet graphic coal sections.

Lewis, R. Q., Sr., and Taylor, A. R., 1974, Geologic map of the Coppersville quadrangle, Wayne and McCreary Counties, Kentucky: U.S. Geol. Survey open-file rept. 74-62, 3 sheets, geologic map, scale $1: 24,000$, coal sections, stratigraphic sections.

Love, J. D., 1973, Preliminary geologic map of the Two Ocean Lake quadrangle, Teton County, Wyoming: U.S. Geol. Survey open-file map, scale 1:24,000, 6 p.

Love, J. D., and Albee, H. F., 1972, Geologic map of the Jackson quadrangle, Teton County, Wyoming: U.S. Geol. Survey Misc. Geol. Inv. Map I-769-A, scale 1:24,000.

Mapel, W. J., 1973, Preliminary geologic map of the Rawhide School quadrangle, Campbell County, Wyoming: U.S. Geol. Survey open-file rept., 2 sheets, geologic map, scale $1: 24,000$, measured coal sections, and well and surface correlations.

1974, Preliminary geologic map and coal sections of the Bar N Draw quadrangle, Wyoming-Montana: U.S. Geol. Survey open-file rept. 74-63, 3 sheets, geologic map, scale $1: 24,000$, coal sections, logs of drill holes.

Maughan, E. K., and Tazelaar, J. F., 1973, Geologic map of part of the Rose Hill quadrangle, Harlan County, Kentucky: U.S. Geol. Survey Geol. Quad. Map GQ-1121, scale 1:24,000 [1974].

Merewether, E. A., 1971a, Geology of the Knoxville and Delaware quadrangles, Johnson and Logan Counties and vicinity, Arkansas: U.S. Geol. Survey Prof. Paper 657-B, p. B1-B18, plates.

$1971 b$, Geologic map of the Wild Horse Mountain quadrangle, Carbon County, Wyoming: U.S. Geol. Survey Geol. Quad. Map GQ-887, scale 1:24,000.

1972, Geologic map of the Seminoe Dam SW quadrangle, Carbon County, Wyoming: U.S. Geol. Survey Geol. Quad. Map GQ-1017, scale 1:24,000.

1973, Geologic map of the Lone Haystack Mountain quadrangle, Carbon County, Wyoming: U.S. Geol. Survey Geol. Quad. Map GQ-1064, scale 1:24,000 [1974].

Miller, R. L., and Meissner, C. R., 1973, Geologic map of the Big A Mountain quadrangle, Buchanan and Russell Counties, Virginia: U.S. Geol. Survey open-file rept., geologic map, scale $1: 24,000$, structure sections, stratigraphic columns, text, $28 \mathrm{p}$.

Miller, R. L., and Roen, J. B., 1973, Geologic map of the Pennington Gap quadrangle, Lee County, Virginia, and Harlan County, Kentucky: U.S. Geol. Survey Geol. Quad. Map GQ-1098, scale 1:24,000 [1974].

McKay, E. J., 1972, Geologic map of the Show Low quadrangle, Navajo County, Arizona: U.S. Geol. Survey Geol. Quad. Map GQ-973, scale 1:62,500.

1973a, Preliminary geologic map of the Croton $1 \mathrm{NE}$ quadrangle, Campbell County, Wyoming: U.S. Geol. Survey open-file rept., 3 sheets, geologic map, scale $1: 24,000$, measured coal sections, and well and surface correlations.

$1973 \mathrm{~b}$, Preliminary geologic map of the Croton $1 \mathrm{NW}$ quadrangle, Campbell County, Wyoming: U.S. Geol. Survey open-file rept., 3 sheets, geologic map, scale $1: 24,000$, measured coal sections, and well and surface correlations.

McKay, E. J., and Mapel, W. J., 1973, Preliminary geologic map of the Calf Creek quadrangle, Campbell County, Wyoming: U.S. Geol. Survey open-file rept., 2 sheets, geologic map, scale 1:24,000, measured coal sections, and well and surface correlations.

McLaughlin, R. J., and Hayes, P. T., 1973, Preliminary geologic map of the Townsend Spring quadrangle, Campbell County, Wyoming: U.S. Geol. Survey Misc. Field Studies Map MF-545, scale 1:24,000 [1974].

McLaughlin, R. J., and McKay, E. J., 1973, Preliminary geologic map of the Pitch Draw quadrangle, Campbell County, Wyoming: U.S. Geol. Survey open-file rept., 3 sheets, geologic map, scale 1:24,000, measured coal sections, and well and surface correlations.

Newell, W. L., 1974, Geologic map of the Frakes quadrangle and part of the Eagan quadrangle, southeastern Kentucky: U.S. Geol. Survey open-file map, scale 1:24,000, 2 sheets.

Norris, R. L., 1973a, Map showing bedrock topography and subcrop of selected beds beneath alluvial deposits of the Curdsville quadrangle, western Kentucky: U.S. Geol. Survey Misc. Geol. Inv. Map I-765, scale 1:24,000.

$1973 \mathrm{~b}$, Map showing bedrock topography and subcrop of selected beds beneath alluvial deposits of the Reed quadrangle, Kentucky-Indiana: U.S. Geol. Survey Misc. Geol. Inv. Map I-802, scale 1:24,000.

$1973 \mathrm{c}$, Map showing bedrock topography and subcrop of selected beds beneath alluvial deposits of the Spottsville quadrangle, Henderson County, Kentucky: U.S. Geol. Survey Misc. Geol. Inv. Map I-814, scale 1:24,000. 
1973d, Map showing bedrock topography and subcrop of selected beds beneath alluvial deposits of the Delaware quadrangle, western Kentucky: U.S. Geol. Survey Misc. Geol. Inv. Map I-825, scale 1:24,000.

Olive, W. W., 1971, Geologic map of the Blandville quadrangle, Ballard and Carlisle Counties, Kentucky: U.S. Geol. Survey Geol. Quad. Map GQ-938, scale 1:24,000.

1974, Geologic map of the Wickliffe quadrangle, Kentucky-Missouri, and the part of the Wyatt quadrangle in Kentucky: U.S. Geol. Survey Geol. Quad. Map GQ-1161, scale $1: 24,000$.

Osterwald, F. W., Bennetti, J. B., Jr., and Dunrud, C. R., 1973, Preliminary investigation of seismic tremors in the general area of the Leyden coal mine gas-storage reservoir, Colorado: U.S. Geol. Survey open-file rept., 23 p., 7 figs.

Osterwald, F. W., Dunrud, C. R., Bennetti, J. B., Jr., and Maberry, J. O., 1972, Instrumentation studies of earth tremors related to geology and to mining at the Somerset coal mine, Colorado: U.S. Geol. Survey Prof. Paper 762, $27 \mathrm{p}$.

Osterwald, F. W., and Maberry, J. O., 1974, Engineering geologic map of the Woodside quadrangle, Emery and Carbon Counties, Utah: U.S. Geol. Survey Misc. Geol. Inv. Map 1-798, scale 1:62,500.

O'Sullivan, R. B., Repenning, C. A., Beaumont, E. C., and Page, H. G., 1972, Stratigraphy of the Cretaceous rocks and the Tertiary Ojo Alamo Sandstone, Navajo and Hopi Indian Reservations, Arizona, New Mexico, and Utah: U.S. Geol. Survey Prof. Paper 521-E, p. E1-E65, plate.

Page, N. J, Simons, F. S., and Dohrenwend, J. C., 1973, Reconnaissance geologic map of the Mount Wood quadrangle, Montana: U.S. Geol. Survey Misc. Field Studies Map MF491, scale $1: 62,500$.

Palmer, J. E., 1972, Geologic map of the Central City East quadrangle, Muhlenberg and Ohio Counties, Kentucky: U.S. Geol. Survey Geol. Quad. Map GQ-1031, scale $1: 24,000$.

Patterson, E. D., and Van Lieu, J. A., 1971, Coal resources of Butler County, Pennsylvania: U.S. Geol. Survey Bull. 1143C, p. C1-C43, plates.

1972, Geologic and coal-bed map of Clarion County, Pennsylvania: U.S. Geol. Survey Misc. Geol. Inv. Map I715 , scale $1: 62,500$.

Patton, W. W., Jr., 1973, Reconnaissance geology of the northern Yukon-Koyukuk province, Alaska: U.S. Geol. Survey Prof. Paper 774-A, p. A1-A17.

Peterson, Fred, 1973, Geologic map of the southwest quarter of the Gunsight Butte quadrangle, Kane and San Juan Counties, Utah, and Coconino County, Arizona: U.S. Geol. Survey Misc. Field Studies Map MF-306, scale 1:24,000 [1974].

Peterson, Fred, and Barnum, B. E., 1973, Geologic map and coal resources of the northeast quarter of the Cummings Mesa quadrangle, Kane County, Utah: U.S. Geol. Survey Coal Inv. Map C-63, 2 sheets, geologic map, scale 1:24,000, coal sections [1974].

Pillmore, C. L., 1974, Geologic and structure contour maps of the Ute Creek 1 SE quadrangle, Colfax County, New Mexico: U.S. Geol. Survey open-file rept., 2 sheets, scale $1: 24,000$.

Reynolds, M. W., 1971, Geologic map of the Lamont quadrangle, Carbon County, Wyoming: U.S. Geol. Survey Geol. Quad. Map GQ-912, scale 1:24,000.
Rice, C. L., 1972, Geologic map of the Alcorn quadrangle, eastcentral Kentucky: U.S. Geol. Survey Geol. Quad. Map GQ963, scale 1:24,000.

1973, Geologic map of the Jenkins West quadrangle, Kentucky-Virginia: U.S. Geol. Survey Geol. Quad. Map GQ-1126, scale 1:24,000 [1974].

Rice, C. L., and Wolcott, D. E., 1973, Geologic map of the Whitesburg quadrangle, Kentucky-Virginia, and part of the Flat Gap quadrangle, Letcher County, Kentucky: U.S. Geol. Survey Geol. Quad. Map GQ-1119, scale 1:24,000 [1974].

Richardson, E. E., Wayland, R. G., and Smith, M. B., 1972, Geologic map of the southeast quarter of the Priest Valley quadrangle, Fresno and Monterey Counties, California: U.S. Geol. Survey Misc. Field Studies Map MF-303, scale $1: 31,680$.

Roberts, A. E., 1972, Cretaceous and early Tertiary depositional and tectonic history of the Livingston area, southwestern Montana: U.S. Geol. Survey Prof. Paper 526-C, p. C1-C120, plates.

Roehler, H. W., 1972a, Geologic map of the Red Creek Ranch quadrangle, Wyoming, Utah, and Colorado: U.S. Geol. Survey Geol. Quad. Map GQ-1001, scale 1:24,000.

$1972 \mathrm{~b}$, Geologic map of the Four J Rim quadrangle, Sweetwater County, Wyoming, and Moffat County, Colorado: U.S. Geol. Survey Geol. Quad. Map GQ-1002, scale $1: 24,000$.

1972c, Geologic map of the Brushy Point quadrangle, Rio Blanco and Garfield Counties, Colorado: U.S. Geol. Survey Geol. Quad. Map GQ-1018, scale 1:24,000.

1972d, Geologic map of the Razorback Ridge quadrangle, Rio Blanco and Garfield Counties, Colorado: U.S. Geol. Survey Geol. Quad. Map GQ-1019, scale 1:24,000.

1973a, Geologic map of the Erickson-Kent Ranch quadrangle, Sweetwater County, Wyoming: U.S. Geol. Survey Geol. Quad. Map GQ-1056, scale 1:24,000.

$1973 \mathrm{~b}$, Geologic map of the Potter Mountain quadrangle, Sweetwater County, Wyoming: U.S. Geol. Survey Geol. Quad. Map GQ-1082, scale 1:24,000.

1973c, Geologic map of the Titsworth Gap quadrangle, Sweetwater County, Wyoming: U.S. Geol. Survey Geol. Quad. Map GQ-1083, scale 1:24,000 [1974].

1973d, Geologic map of the Calf Canyon quadrangle, Garfield County, Colorado: U.S. Geol. Survey Geol. Quad. Map GQ-1086, scale 1:24,000 [1974].

$1973 \mathrm{e}$, Geologic map of the Henderson Ridge quadrangle, Garfield County, Colorado: U.S. Geol. Survey Geol. Quad. Map GQ-1113, scale 1:24,000 [1974].

Roen, J. B., 1971, Preliminary geologic map of the Midway quadrangle, Washington County, southwestern Pennsylvania: U.S. Geol. Survey Misc. Field Studies Map MF319,2 sheets, scale 1:24,000 [1972].

1972, Geologic map of the Oak Forest quadrangle and part of the Blacksville quadrangle, southwestern Pennsylvania: U.S. Geol. Survey Misc. Geol. Inv. Map I-699, scale $1: 24,000$ [1973].

1973, Geologic map of the Midway quadrangle, Washington County, southwestern Pennsylvania: U.S. Geol. Survey Geol. Quad. Map GQ-1067, scale 1:24,000.

Roen, J. B., and Farrel, D. E., 1973, Structure contour map of the Pittsburgh coal bed, southwestern Pennsylvania and northern West Virginia: U.S. Geol. Survey open-file map, scale $1: 125,000$. 
Romero, J. C., and Hampton, E. R., 1972, Maps showing the approximate configuration and depth to the top of the Laramie-Fox Hills aquifer, Denver basin, Colorado: U.S. Geol. Survey Misc. Geol. Inv. Map I-791, scale 1:500,000.

Schell, E. M., and Mowat, G. D., 1972, Reconnaissance map showing some coal and clinker beds in the Fort Union and Wasatch Formations in the eastern Powder River Basin, Campbell and Converse Counties, Wyoming: U.S. Geol. Survey open-file rept., 3 maps, scale 1:63,360, separate text.

Schlanger, S. O., and Weir, G. W., 1971, Geologic map of the Mount Vernon quadrangle, Rockcastle County, Kentucky: U.S. Geol. Survey Geol. Quad. Map GQ-902, scale 1:24,000.

Schroeder, M. L., 1972, Geologic map of the Rendezvous Peak quadrangle, Teton County, Wyoming: U.S. Geol. Survey Geol. Quad. Map GQ-980, scale 1:24,000.

Schweinfurth, S. P., 1972a, Structure contour map of the Avella and part of the Steubenville East quadrangles, Washington County, Pennsylvania: U.S. Geol. Survey open-file map, scale $1: 24,000$.

$1972 \mathrm{~b}$, Structure contour map of the West Middletown and part of the Bethany quadrangles, Washington County, Pennsylvania: U.S. Geol. Survey open-file map, scale 1:24,000.

Shown, L. M., 1973, Land use map of the Gillette area, Wyoming, 1970: U.S. Geol. Survey Misc. Geol. Inv. Map I-848A, scale 1:125,000.

Smith, A. E., and Ball, T. E., 1973, Map showing bedrock topography and subcrop of a selected bed beneath alluvial deposits of part of the Evansville South quadrangle, Henderson County, Kentucky: U.S. Geol. Survey Misc. Geol. Inv. Map I-826, scale 1:24,000.

Smith, H. L., 1973, Geologic map and lignite deposits of the New Salem quadrangle, Morton County, North Dakota: U.S. Geol. Survey Coal Inv. Map C-62, scale 1:24,000 [1974].

Smith, J. H., Pomerene, J. B., and Ping, R. G., 1973, Geologic map of the Hail quadrangle, McCreary and Pulaski Counties, Kentucky: U.S. Geol. Survey Geol. Quad. Map GQ1058 , scale $1: 24,000$.

Soister, P. E., 1972a, Geologic map of the Peoria quadrangle, Arapahoe and Adams Counties, Colorado: U.S. Geol. Survey Geol. Quad. Map GQ-875, scale 1:24,000.

1972b, Preliminary geologic map and lignite deposits of the Strasburg NW quadrangle, Arapahoe and Adams Counties, Colorado: U.S. Geol. Survey open-file rept., geologic map, scale $1: 24,000,2$ sheets graphic coal sections.

1974, A preliminary report on a zone containing thick lignite beds, Denver basin, Colorado: U.S. Geol. Survey open-file rept. 74-27, 64 p., 4 tables, 6 figs., geologic map, scale 1:250,000.

Soward, K. S., 1972a, Preliminary geologic map of the White Butte West quadrangle, Hettinger County, North Dakota: U.S. Geol. Survey open-file map, scale 1:24,000, coal sections.

1972b, Preliminary geologic map of the White Butte East quadrangle, Hettinger County, North Dakota: U.S. Geol. Survey open-file map, scale 1:24,000, coal sections.

1972c, Preliminary geologic map of the White Butte NE quadrangle, Stark and Hettinger Counties, North Dakota: U.S. Geol. Survey open-file map, scale 1:24,000, coal sections.

1972d, Preliminary geologic map of the White Butte NW quadrangle, Stark and Hettinger Counties, North Dakota:
U.S. Geol. Survey open-file map, scale 1:24,000, coal sections.

Spencer, F. D., 1972a, Availability of low-sulfur coal in Mingo County, West Virginia: U.S. Geol. Survey open-file rept., 24 p., 3 figs., 1 table.

1972b, Availability of low-sulfur coal in Wayne County, West Virginia: U.S. Geol. Survey open-file rept., 19 p., 3 figs., 1 table.

Stephens, E. V., 1973, Geologic map and coal resources of the Wide Hollow Reservoir quadrangle, Garfield County, Utah: U.S. Geol. Survey Coal Inv. Map C-55, scale 1:24,000.

Tazelaar, J. F., and Newell, W. L., 1974, Geologic map of the Evarts quadrangle and part of the Hubbard Springs quadrangle, southeastern Kentucky and Virginia: U.S. Geol. Survey Geol. Quad. Map GQ-914, scale 1:24,000.

Theobald, P. K., Schweinfurth, S. P., and Duncan, D. C., 1972, Energy resources of the United States: U.S. Geol. Survey Circ. 650, 27 p. [Repr. 1973.]

Trace, R. D., and Palmer, J. E., 1971, Geologic map of the Shady Grove quadrangle, Crittenden and Caldwell Counties, Kentucky: U.S. Geol. Survey Geol. Quad. Map GQ880 , scale $1: 24,000$.

Trimble, D. E., 1974, Geologic map of the Niwot quadrangle, Boulder County, Colorado: U.S. Geol. Survey open-file map 74-10, scale 1:24,000, 1 plate.

U.S. Department of the Interior, 1972a, Coal resources and reserves of the southwestern United States, Pt. 1 in Appendix J of Southwest energy study; Coal Resources Work Group: U.S. Geol. Survey open-file rept., 72 p.

$1972 \mathrm{~b}$, Composition and trace element content of coal and power plant ash, Pt. 2 in Appendix J of Southwest energy study; Coal Resources Work Group: U.S. Geol. Survey open-file rept., $61 \mathrm{p}$.

1973, Draft environmental statement, proposed plan of mining and reclamation, Big Sky mine, Peabody Coal Co., Coal Lease M-15965, Colstrip, Montana: DES 73-64, U.S. Geol. Survey open-file rept., 427 p.

U.S. Geological Survey, 1973, Land and coal ownership in the Gillette area, Wyoming: U.S. Geol. Survey Misc. Geol. Inv. Map I-848-B, scale 1:125,000.

1974, Stripping coal deposits of the Northern Great Plains, Montana, Wyoming, North Dakota, and South Dakota: U.S. Geol. Survey Misc. Field Inv. Map MF-590, scale $1: 1,000,000$.

U.S. Geological Survey and Montana Bureau of Mines and Geology, 1973, Preliminary report of coal drill-hole data and chemical analyses of coal beds in Sheridan and Campbell Counties, Wyoming, and Big Horn County, Montana: U.S. Geol. Survey open-file rept., 51 p. data and analyses, 3 p. text, and 3 tables.

1974, Preliminary report of coal drill-hole data and chemical analyses of coal beds in Campbell County, Wyoming: U.S. Geol. Survey open-file rept. 74-97, 241 p., 1 fig., 3 tables.

Van Horn, Richard, 1972, Surficial and bedrock geologic map of the Golden quadrangle, Jefferson County, Colorado: U.S. Geol. Survey Misc. Geol. Inv. Map I-761-A, scale 1:24,000.

Wahrhaftig, Clyde, 1973, Coal reserves of the Healy Creek and Lignite Creek coal basins, Nenana coal field, Alaska: U.S. Geol. Survey open-file rept., geologic map, scale 1:40,000, structure contour map, 8 sheets columnar sections, 8 isopach maps, 9 coal reserve maps. 
Weir, G. W., Lee, K. Y., and Cassity, P. E., 1971, Geologic map of the Bighill quadrangle, east-central Kentucky: U.S. Geol. Survey Geol. Quad. Map GQ-900, scale 1:24,000.

Weir, G. W., and Mumma, M. D., 1973, Geologic map of the McKee quadrangle, Jackson County, Kentucky: U.S. Geol. Survey Geol. Quad. Map GQ-1125, scale 1:24,000 [1974].

Williams, P. L., and Hackman, R. J., 1971, Geology, structure, and uranium deposits of the Salina quadrangle, Utah: U.S. Geol. Survey Misc. Geol. Inv. Map I-591, 2 sheets, scale $1: 250,000$.

Witkind, I. J., 1971, Geologic map of the Barker quadrangle, Judith Basin and Cascade Counties, Montana: U.S. Geol. Survey Geol. Quad. Map GQ-898, scale 1:62,500.

Wood, G. H., Jr., 1972a, Geologic map of anthracite-bearing rocks in the Pottsville quadrangle, Schuylkill County, Pennsylvania: U.S. Geol. Survey Misc. Geol. Inv. Map I681,2 sheets, scale $1: 12,000$.

$1972 \mathrm{~b}$, Geologic map of anthracite-bearing rocks in the north part of the Orwigsburg quadrangle, Schuylkill County, Pennsylvania: U.S. Geol. Survey Misc. Geol. Inv. Map I-689, scale 1:12,000.

1973a, Geologic map of the Pottsville quadrangle, Schuylkill County, Pennsylvania: U.S. Geol. Survey Geol. Quad. Map GQ-1028, scale 1:24,000.
$1973 b$, Geologic map of the Orwigsburg quadrangle, Schuylkill County, Pennsylvania: U.S. Geol. Survey Geol. Quad. Map GQ-1029, scale 1:24,000.

Wood, G. H., Jr., and Arndt, H. H., 1973, Geologic map of the Delano quadrangle, Schuylkill County, Pennsylvania: U.S. Geol. Survey Geol. Quad. Map GQ-1054, scale 1:24,000.

Zeller, H. D., 1973a, Geologic map and coal resources of the Carcass Canyon quadrangle, Garfield and Kane Counties, Utah: U.S. Geol. Survey Coal Inv. Map C-56, 2 sheets, geologic map, scale 1:24,000, coal sections [1974].

$1973 b$, Geologic map and coal and oil resources of the Canaan Creek quadrangle, Garfield County, Utah: U.S. Geol. Survey Coal Inv. Map C-57, 2 sheets, geologic map, scale 1:24,000, coal sections [1974].

1973c, Geologic map and coal resources of the Death Ridge quadrangle, Garfield and Kane Counties, Utah: U.S. Geol. Survey Coal Inv. Map C-58, scale 1:24,000.

1973d, Geologic map and coal resources of the Dave Canyon quadrangle, Garfield County, Utah: U.S. Geol. Survey Coal Inv. Map C-59, scale 1:24,000.

Zeller, H. D., and Stephens, E. V., 1972, Preliminary geologic map and coal resources of the Seep Flat quadrangle, Garfield and Kane Counties, Utah: U.S. Geol. Survey open-file rept., geologic map, scale 1:24,000, 1 sheet graphic coal sections.

\section{NOTES AND ADDITIONS}


NOTES AND ADDITIONS - CONTINUED 


\section{INDEX}

\section{ALASKA}

Nenana coal field

Healy Creek and Lignite Creek: Wahrhaftig, 1973.

Yukon-Koyukuk province

Reconnaissance geology: Patton, 1973.

\section{ARIZONA}

Apache County

Stratigraphy, Cretaceous rocks: O'Sullivan and others, 1972.

Coal resources: U.S. Dept. Interior, 1972a,

Coconino County

Stratigraphy, Cretaceous rocks: O'Sullivan and others, 1972.

Minor elements in coal: U.S. Dept. Interior,1972b.

Minor elements in power plant ash: U.S. Dept. Interior, 1972b.

Navajo County

Show Low quadrangle: McKay, 1972.

Stratigraphy, Cretaceous rocks: O'Sullivan and others, 1972.

Navajo and Hopi Indian Reservations

Stratigraphy, Cretaceous rocks: O'Sullivan and others, 1972.

\section{ARKANSAS}

Crawford County

Lavaca quadrangle: Haley and Hendricks, 1971.

Van Buren quadrangle: Haley and Hendricks, 1971.

Franklin County

Lavaca quadrangle: Haley and Hendricks, 1971.

Johnson County

Delaware quadrangle: Merewether, 1971a.

Knoxville quadrangle: Merewether, 1971a.

Logan County

Delaware quadrangle: Merewether, 1971a.

Pope County

Delaware quadrangle: Merewether, 1971a.

Knoxville quadrangle: Merewether, 1971a.

Sebastian County

Lavaca quadrangle: Haley and Hendricks, 1971.

Van Buren quadrangle: Haley and Hendricks, 1971.

Yell County

Delaware quadrangle: Merewether, 1971a.

\section{BIBLIOGRAPHY}

Minor elements in coal: Averitt and others, 1972.

Pennsylvania, southwestern part

Index to large-scale geologic mapping: Briggs, 1973.

U.S. Geological Survey publications relating to coal, 18821970: Averitt and Lopez, 1972.

\section{CALIFORNIA}

Fresno County

Priest Valley quadrangle: Richardson and others, 1972.

Monterey County

Priest Valley quadrangle: Richardson and others, 1972.
COAL RESOURCES

Southwestern United States: U.S. Dept. Interior, 1972a.

United States: Averitt, 1973.

COLORADO

Adams County

Boulder-Weld coal field: Colton and Lowrie, 1973.

Peoria quadrangle: Soister, 1972a.

Strasburg NW quadrangle: Soister, 1972b.

Watkins area: Soister, 1974.

Arapahoe County

Peoria quadrangle: Soister, 1972a.

Strasburg NW quadrangle: Soister, 1972b.

Watkins area: Soister, 1974.

Boulder County

Boulder-Weld coal field: Colton and Lowrie, 1973.

Niwot quadrangle: Trimble, 1974.

Coal resources

Tabulated by bed: Landis and Cone, 1971.

U.S. Dept. Interior, 1972a.

Cortez quadrangle

Dolores, Montezuma, and San Miguel Counties:

Haynes and others, 1972.

Delta County

Cedaredge area: Hail, 1972a.

Grand Junction quadrangle: Cashion, 1973.

Denver basin

Structure, top Laramie-Fox Hills aquifer: Romero and Hampton, 1972.

See also individual counties.

Dolores County

Cortez quadrangle: Haynes and others, 1972.

Garfield County

Brushy Point quadrangle: Roehler, 1972c.

Calf Canyon quadrangle: Roehler, 1973d.

Grand Junction quadrangle: Cashion, 1973.

Henderson Ridge quadrangle: Roehler, 1973e.

Razorback Ridge quadrangle: Roehler, 1972d.

Grand County

Hyannis Peak quadrangle: Kinney and Hail, 1970a.

Rand quadrangle: Kinney, 1970b.

Grand Junction quadrangle

Delta, Garfield, Mesa, and Rio Blanco Counties: Cashion, 1973.

Gunnison County

Somerset mine, seismic tremors: Osterwald and others, 1972.

Jackson County

Cowdrey quadrangle: Kinney and others, 1970.

Gould quadrangle: Kinney, 1970a.

Hyannis Peak quadrangle: Kinney and Hail, 1970a.

Kings Canyon quadrangle: Kinney, 1971.

Rand quadrangle: Kinney, 1970b.

Walden quadrangle: Kinney and Hail, $1970 \mathrm{~b}$. 
COLORADO-Cont.

Jefferson County

Golden quadrangle: Van Horn, 1972.

Leyden coal mine, gas storage reservoir, seismic tremors: Osterwald and others, 1973.

Mesa County

Grand Junction quadrangle: Cashion, 1973.

Middle Park

See Grand County.

Minor elements in coal: U.S. Dept. Interior, 1972b.

Minor elements in power plant ash: U.S. Dept. Interior, 1972b.

Moffat County

Four J Rim quadrangle: Roehler, 1972b.

Red Creek Ranch quadrangle: Roehler, 1972a.

Smizer Gulch quadrangle: Hail, 1974.

Montezuma County

Cortez quadrangle: Haynes and others, 1972.

North Park

See Jackson County

Rio Blanco County

Barcus Creek SE quadrangle: Hail, 1972b.

Brushy Point quadrangle: Roehler, 1972c.

Grand Junction quadrangle: Cashion, 1973.

Rangely quadrangle: Cullins, 1971.

Razorback Ridge quadrangle: Roehler, 1972d.

Smizer Gulch quadrangle: Hail, 1974.

San Juan Basin

Geology, fuel resources, Fruitland Formation and

Kirtland Shale: Fassett and Hinds, 1971.

San Miguel County

Cortez quadrangle: Haynes and others, 1972.

Watkins area

Adams and Arapahoe Counties: Soister, 1974.

Weld County

Boulder-Weld coal field: Colton and Lowrie, 1973.

\section{INDIANA}

Spencer County

Reed quadrangle: Johnson, 1972a.

Reed quadrangle: Norris, $1973 \mathrm{~b}$.

\section{KENTUCKY}

Ballard County

Blandville quadrangle: Olive, 1971.

Wickliffe quadrangle: Olive, 1974.

Bath County

Bangor quadrangle: Hylbert and Philley, 1971.

Bell County

Balkan quadrangle: Froelich and Tazelaar, 1973.

Eagan quadrangle: Newell, 1974.

Frakes quadrangle: Newell, 1974.

Pineville quadrangle: Froelich, 1973b.

Wallins Creek quadrangle: Froelich, 1972.

Boyd County

Webbville quadrangle: Carlson, 1971.

Butler County

Flener quadrangle: Gildersleeve, $1972 \mathrm{~b}$.

Morgantown quadrangle: Gildersleeve, 1972a.

Rosine quadrangle: Johnson, 1971b.

Caldwell County

Dawson Springs SW quadrangle: Hansen, 1973.

Shady Grove quadrangle: Trace and Palmer, 1971.
KENTUCKY—Cont.

Carter County

Ault quadrangle: DeLaney and Englund, 1973.

Webbville quadrangle: Carlson, 1971.

Christian County

Dawson Springs SW quadrangle: Hansen, 1973.

Crittenden County

Dekoven quadrangle: Kehn, 1974.

Shady Grove quadrangle: Trace and Palmer, 1971.

Daviess County

Curdsville quadrangle: Fairer and Norris, 1972.

Curdsville quadrangle: Norris, 1973a.

Delaware quadrangle: Johnson, $1973 \mathrm{~b}$.

Delaware quadrangle: Norris, 1973d.

Glenville quadrangle: Johnson and Smith, 1972b.

Owensboro West quadrangle: Goudarzi and Smith, 1971.

Panther quadrangle: Goudarzi, 1971.

Reed quadrangle: Johnson, 1972a.

Reed quadrangle: Norris, 1973b.

Utica quadrangle: Johnson and Smith, 1972a.

Yankeetown quadrangle: Johnson, 1972b.

Eastern coal field

Paleobotany, Pennsylvanian rocks: Kosanke, 1972.

Paleobotany, Pennsylvanian rocks: Kosanke, 1973.

See also individual counties.

Edmonson County

Nolin Reservoir quadrangle: Gildersleeve, 1971.

Elliott County

Ault quadrangle: DeLaney and Englund, 1973.

Estill County

Alcorn quadrangle: Rice, 1972.

Gray County

Rosine quadrangle: Johnson, 1971b.

Grayson County

Nolin Reservoir quadrangle: Gildersleeve, 1971.

Harlan County

Balkan quadrangle: Froelich and Tazelaar, 1973.

Benham quadrangle: Froelich and Stone, 1973.

Bledsoe quadrangle: Csejtey, 1971.

Evarts quadrangle: Tazelaar and Newell, 1974.

Harlan quadrangle: Froelich and McKay, 1972.

Hubbard Springs quadrangle: Tazelaar and Newell, 1974.

Louellen quadrangle: Froelich, 1973a.

Pennington Gap quadrangle: Miller and Roen, 1973.

Rose Hill quadrangle: Maughan and Tazelaar, 1973.

Wallins Creek quadrangle: Froelich, 1972.

Hart County

Nolin Reservoir quadrangle: Gildersleeve, 1971.

Henderson County

Curdsville quadrangle: Fairer and Norris, 1972.

Curdsville quadrangle: Norris, 1973a.

Delaware quadrangle: Johnson, 1973b.

Delaware quadrangle: Norris, 1973d.

Evansville South quadrangle: Johnson, 1973d.

Evansville South quadrangle: Smith and Ball, 1973.

Henderson quadrangle: Ball, 1973.

Henderson quadrangle: Johnson, 1973a.

Newburgh quadrangle: Johnson, 1972b.

Poole quadrangle: Fairer, 1973b.

Reed quadrangle: Johnson, 1972a. 


\section{KENTUCKY - Cont.}

Henderson County - Cont.

Reed quadrangle: Norris, $1973 \mathrm{~b}$.

Robards quadrangle: Fairer, 1973a.

Spottsville quadrangle: Johnson, 1973c.

Spottsville quadrangle: Norris, $1973 \mathrm{c}$.

Yankeetown quadrangle: Johnson, 1972b.

Hopkins County

Millport quadrangle: Franklin, 1973.

Jackson County

Alcorn quadrangle: Rice, 1972.

Bighill quadrangle: Weir and others, 1971.

McKee quadrangle: Weir and Mumma, 1973.

Sandgap quadrangle: Gualtieri, 1973.

Knox County

Frakes quadrangle: Newell, 1974.

Pineville quadrangle: Froelich, 1973.

Lawrence County

Webbville quadrangle: Carlson, 1971.

Leslie County

Bledsoe quadrangle: Csejtey, 1971.

Letcher County

Appalachia quadrangle: Froelich and Stone, 1973.

Benham quadrangle: Froelich and Stone, 1973.

Flat Gap quadrangle: Rice and Wolcott, 1973.

Jenkins West quadrangle: Rice, 1973.

Louellen quadrangle: Froelich, 1973.

Whitesburg quadrangle: Rice and Wolcott, 1973.

Madison County

Alcorn quadrangle: Rice, 1972.

Bighill quadrangle: Weir and others, 1971.

McCreary County

Coppersville quadrangle: Lewis and Taylor, 1974.

Hail quadrangle: Smith and others, 1973.

McLean County

Curdsville quadrangle: Fairer and Norris, 1972.

Curdsville quadrangle: Norris, 1973a.

Delaware quadrangle: Johnson, 1973b.

Delaware quadrangle: Norris, 1973d.

Glenville quadrangle: Johnson and Smith, $1972 b$.

Utica quadrangle: Johnson and Smith, 1972a.

Menifee County

Bangor quadrangle: Hylbert and Philley, 1971.

Morgan County

Bangor quadrangle: Hylbert and Philley, 1971.

Muhlenberg County

Central City East quadrangle: Palmer, 1972.

Drakesboro quadrangle: Hansen, 1972.

Greenville quadrangle: Kehn, 1971.

Millport quadrangle: Franklin, 1973.

Ohio County

Central City East quadrangle: Palmer, 1972.

Flener quadrangle: Gildersleeve, 1972b.

Horton quadrangle: Johnson, 1971a.

Rosine quadrangle: Johnson, 1971b.

Utica quadrangle: Johnson and Smith, 1972a.

Perry County

Louellen quadrangle: Froelich, 1973.

Pike County

Clintwood quadrangle: Alvord, 1971.

Elkhorn City quadrangle: Alvord and Miller, 1972.

Harmon quadrangle: Alvord and Miller, 1972.
KENTUCKY-Cont.

Pike County - Cont.

Hellier quadrangle: Alvord, 1971.

Jenkins West quadrangle: Rice, 1973.

Pulaski County

Hail quadrangle: Smith and others, 1973.

Rockcastle County

Bighill quandrangle: Weir and others, 1971.

Mount Vernon quadrangle: Schlanger and Weir, 1971.

Rowan County

Ault quadrangle: DeLaney and Englund, 1973.

Bangor quadrangle: Hylbert and Philley, 1971.

Morehead quadrangle: Hoge and Chaplin, 1972.

Union County

Dekoven quadrangle: Kehn, 1974.

Saline Mines quadrangle: Kehn, 1974.

Warren County

Morgantown quadrangle: Gildersleeve, 1972a.

Wayne County

Coppersville quadrangle: Lewis and Taylor, 1974.

Webster County

Poole quadrangle: Fairer, 1973b.

Robards quadrangle: Fairer, 1973a.

Western coal field

Sturgis Formation, stratigraphy: Kehn, 1973.

Tradewater River basin, effects of coal mining on water resources: Grubb and Ryder, 1972.

See also individual counties.

Whitley County

Eagan quadrangle: Newell, 1974.

Frakes quadrangle: Newell, 1974.

MINOR ELEMENTS IN COAL

Bibliography: Averitt and others, 1972.

Southwestern United States: U.S. Dept. Interior, 1972b.

MONTANA

Big Horn County

Bar N Draw quadrangle: Mapel, 1974.

Coal drill-hole data: U.S. Geol. Survey and Montana

Bur. Mines and Geology, 1973.

Decker quadrangle: Law and Grazia, 1972.

Moorhead coal field: Bryson and Bass, 1973.

Ranchester quadrangle: Barnum, 1974.

Cascade County

Barker quadrangle: Witkind, 1971.

Judith Basin County

Barker quadrangle: Witkind, 1971.

Moorhead coal field

Powder River, Big Horn, and Rosebud Counties:

Bryson and Bass, 1973.

Park County

Livingston area: Roberts, 1972.

Powder River Basin

Energy resources map: Keefer and Schmidt, 1973.

Stripping coal deposits: U.S. Geol. Survey, 1974.

See also individual counties.

Powder River County

Moorhead coal field: Bryson and Bass, 1973.

Rosebud County

Big Sky mine, draft environmental statement: U.S. Dept. Interior, 1973.

Moorhead coal field: Bryson and Bass, 1973. 
MONTANA - Cont.

Stillwater County Mount Wood quadrangle: Page and others, 1973.

Stripping coal deposits: U.S. Geol. Survey, 1974.

NEW MEXICO

Coal resources: U.S. Dept. Interior, 1972a.

Colfax County

Ute Creek $1 \mathrm{SE}$ quadrangle: Pillmore, 1974.

McKinley County

Stratigraphy, Cretaceous rocks: O'Sullivan and others, 1972.

Minor elements in coal: U.S. Dept. Interior, $1972 \mathrm{~b}$.

Minor elements in power plant ash: U.S. Dept. Interior, $1972 b$.

Navajo Indian Reservation

Stratigraphy, Cretaceous rocks: O'Sullivan and others, 1972.

San Juan Basin

Geology, fuel resources, Fruitland Formation and Kirtland Shale: Fassett and Hinds, 1971.

San Juan County

Stratigraphy, Cretaceous rocks: O'Sullivan and others, 1972.

\section{NORTH DAKOTA}

Hettinger County

White Butte East quadrangle: Soward, 1972b.

White Butte NE quadrangle: Soward, 1972c.

White Butte NW quadrangle: Soward, 1972d.

White Butte West quadrangle: Soward, 1972a.

Morton County

Dengate quadrangle: Barclay, 1971.

Glen Ullin quadrangle: Barclay, 1973.

New Salem quadrangle: Smith, 1973.

Stark County

White Butte NE quadrangle: Soward, 1972c.

White Butte NW quadrangle: Soward, 1972d.

Stripping coal deposits: U.S. Geol. Survey, 1974.

NORTHERN GREAT PLAINS

Montana, Wyoming, North Dakota, and South Dakota

Stripping coal deposits: U.S. Geol. Survey, 1974.

See also individual States.

OKLAHOMA

LeFlore County

Van Buren quadrangle: Haley and Hendricks, 1971.

Sequoyah County

Van Buren quadrangle: Haley and Hendricks, 1971.

\section{PAKISTAN}

Coal analyses: Landis and others, 1973.

\section{PALEOBOTANY}

Kentucky

Eastern coal field: Kosanke, 1972.

Eastern coal field: Kosanke, 1973.

PENNSYLVANIA

Bibliography, southwestern part Index to large-scale geologic mapping: Briggs, 1973.

Butler County

Coal resources: Patterson and Van Lieu, 1971.

Clarion County

Geologic and coal-bed map: Patterson and Van Lieu, 1972.
PENNSYLVANIA - Cont.

Columbia County

Ashland quadrangle: Arndt, 1971a.

Mount Carmel quadrangle: Arndt, 1971b.

Shamokin quadrangle, south half: Arndt and others, 1973.

Fayette County

Underclay deposits: Hosterman, 1972.

Greene County

Blacksville quadrangle: Roen, 1972.

Garards Fort quadrangle: Kent, 1971.

Masontown quadrangle: Kent, 1973

Morgantown North quadrangle: Kent, 1973.

Oak Forest quadrangle: Roen, 1972.

Osage quadrangle: Kent, 1971.

Prosperity quadrangle: Kent, 1972.

Luzerne County

Wilkes-Barre East quadrangle: Bergin, 1973.

Northumberland County

Mount Carmel quadrangle: Arndt, 1971b.

Shamokin quadrangle, south half: Arndt and others, 1973.

Schuylkill County

Ashland quadrangle: Arndt, 1971a.

Delano quadrangle: Wood and Arndt, 1973.

Mount Carmel quadrangle: Arndt, 1971b.

Orwigsburg quadrangle: Wood, 1972b.

Orwigsburg quadrangle: Wood, 1973b.

Pottsville quadrangle: Wood, 1972a.

Pottsville quadrangle: Wood, 1973a.

Somerset County

Underclay deposits: Hosterman, 1972.

Southwestern part

Index to large-scale geologic mapping: Briggs, 1973.

Pittsburgh coal bed, structure contour map: Roen and Farrel, 1973.

Washington County

Avella quadrangle: Schweinfurth, 1972a.

Bethany quadrangle: Schweinfurth, 1972b.

Economic and engineering geology: Berryhill and others, 1971.

Midway quadrangle: Roen, 1971.

Midway quadrangle: Roen, 1973.

Prosperity quadrangle: Kent, 1972.

Steubenville East quadrangle: Schweinfurth, 1972a.

Stratigraphy, coal-bearing rocks: Berryhill and others, 1971.

West Middletown quadrangle: Schweinfurth, 1972b.

PITTSBURGH COAL BED

Southwestern Pennsylvania and northern West Virginia

Structure contour map: Roen and Farrel, 1973.

SOUTH DAKOTA

Stripping coal deposits: U.S. Geol. Survey, 1974.

UNITED STATES

Bibliography

U.S. Geological Survey publications relating to coal, 1882-1970: Averitt and Lopez, 1972.

Coal resources: Averitt, 1973.

UTAH

Energy resources: Theobald and others, 1972.

Carbon County

Geneva Mine area: Dunrud and Barnes, 1972. 
UTAH - Cont.

Carbon County - Cont.

Sunnyside mining district, seismic activity: Dunrud and others, 1973.

Woodside quadrangle: Osterwald and Maberry, 1974.

Coal resources: U.S. Dept. Interior, 1972a.

Cortez quadrangle

Garfield and San Juan Counties: Haynes and others, 1972.

Daggett County

Red Creek Ranch quadrangle: Roehler, 1972a.

Emery County

Geneva Mine area: Dunrud and Barnes, 1972.

Salina quadrangle: Hackman, 1972.

Salina quadrangle: Williams and Hackman, 1971.

Sunnyside mining district, seismic activity: Dunrud and others, 1973.

Woodside quadrangle: Osterwald and Maberry, 1974.

Garfield County

Canaan Creek quadrangle: Zeller, 1973b.

Carcass Canyon quadrangle: Zeller, 1973a.

Cortez quadrangle: Haynes and others, 1972.

Dave Canyon quadrangle: Zeller, 1973d.

Death Ridge quadrangle: Zeller, 1973c.

Griffin Point quadrangle: Bowers, 1973b.

Henrieville quadrangle: Bowers, 1974.

Pine Lake quadrangle: Bowers, 1972.

Salina quadrangle: Hackman, 1972.

Salina quadrangle: Williams and Hackman, 1971.

Seep Flat quadrangle: Zeller and Stephens, 1972.

Upper Valley quadrangle: Bowers, 1973a.

Wide Hollow Reservoir quadrangle: Stephens, 1973.

Grand County

Grand Junction quadrangle: Cashion, 1973.

Grand Juntion quadrangle

Grand and Uintah Counties: Cashion, 1973.

Kane County

Bald Knoll quadrangle: Goode, 1973a.

Carcass Canyon quadrangle: Zeller, 1973a.

Cummings Mesa quadrangle: Peterson and Barnum, 1973.

Death Ridge quadrangle: Zeller, 1973c.

Gunsight Butte quadrangle: Peterson, 1973.

Henrieville quadrangle: Bowers, 1974.

Seep Flat quadrangle: Zeller and Stephens, 1972.

Skutumpah Creek quadrangle: Goode, 1973b.

Minor elements in coal: U.S. Dept. Interior, 1972b.

Minor elements in power plant ash: U.S. Dept. Interior, $1972 b$.

Navajo Indian Reservation

Stratigraphy, Cretaceous rocks: O'Sullivan and others, 1972.

Salina quadrangle

Emery, Garfield, Sevier, and Wayne Counties: Williams and Hackman, 1971; Hackman, 1972.

San Juan County

Cortez quadrangle: Haynes and others, 1972.

Stratigraphy, Cretaceous rocks: O'Sullivan and others, 1972.

Sevier County

Salina quadrangle: Hackman, 1972.

Salina quadrangle: Williams and Hackman, 1971.
UTAH - Cont.

Uintah County

Grand Junction quadrangle: Cashion, 1973.

Wayne County

Salina quadrangle: Hackman, 1972.

Salina quadrangle: Williams and Hackman, 1971.

VIRGINIA

Buchanan County

Big A Mountain quadrangle: Miller and Meissner, 1973.

Elkhorn City quadrangle: Alvord and Miller, 1972.

Hellier quadrangle: Alvord, 1971.

Lee County

Pennington Gap quadrangle: Miller and Roen, 1973.

Russell County

Big A Mountain quadrangle: Miller and Meissner, 1973.

Wise County

Hubbard Springs quadrangle: Tazelaar and Newell, 1974.

Jenkins West quadrangle: Rice, 1973.

Whitesburg quadrangle: Rice and Wolcott, 1973.

WEST VIRGINIA

Clay County

Low-sulfur coal: Hadley, 1972a.

Fayette County

Low-sulfur coal: Hadley, 1972b.

Greenbrier County

Low-sulfur coal: Englund and Windolph, 1972.

Kanawha County

Low-sulfur coal: Hadley, 1972c.

McDowell County

Low-sulfur coal: Englund, 1972a.

Mercer County

Low-sulfur coal: Englund, 1972b.

Mingo County

Low-sulfur coal: Spencer, 1972a.

Nicholas County

Low-sulfur coal: Hadley, 1972d.

Northern part

Pittsburgh coal bed, structure contour map: Roen and Farrel, 1973.

Raleigh County

Low-sulfur coal: Englund, 1972c.

Wayne County

Low-sulfur coal: Spencer, 1972b.

Wyoming County

Low-sulfur coal: Englund, 1972d.

WYOMING

Campbell County

Calf Creek quadrangle: McKay and Mapel, 1973.

Coal drill-hole data: U.S. Geol. Survey and Montana Bur. Mines and Geology, 1973.

Coal drill-hole data and chemical analyses: U.S. Geol.

Survey and Montana Bur. Mines and Geology, 1974.

Croton 1 NE quadrangle: McKay, 1973a.

Croton $1 \mathrm{NW}$ quadrangle: McKay, 1973b.

Croton 1 SE quadrangle: Landis and Hayes, 1973.

Croton 1 SW quadrangle: Hayes, 1973.

Fortin Draw quadrangle: Law, 1974.

Gap SW quadrangle: Grazis, 1974b.

Gillette area, coal resources: Denson and others, 1973. 
WYOMING - Cont.

Campbell County - Cont.

Gillette area, land and coal ownership: U.S. Geol. Survey, 1973.

Gillette area, land use: Shown, 1973.

Kicken Creek quadrangle: Grazis, 1974d.

Outcrops, coal and clinker beds: Schell and Mowat, 1972.

Pitch Draw quadrangle: McLaughlin and McKay, 1973.

Pleasantdale quadrangle: Grazis, $1974 \mathrm{c}$.

Rawhide School quadrangle: Mapel, 1973.

Scaper Reservoir quadrangle: Grazis, 1974a.

Townsend Spring quadrangle: McLaughlin and Hayes, 1973.

Carbon County

Lamont quadrangle: Reynolds, 1971.

Lone Haystack Mountain quadrangle: Merewether, 1973.

Seminoe Dam SW quadrangle: Merewether, 1972.

Upper Cretaceous rocks, stratigraphic sections: Gill, 1974.

Wild Horse Mountain quadrangle: Merewether, 1971b.

Coal resources: U.S. Dept. Interior, 1972a.

Converse County

Outcrops, coal and clinker beds: Schell and Mowat, 1972.
WYOMING - Cont.

Green River Basin

See individual counties.

Lincoln County

Observation Peak quadrangle: Albee, 1972.

Minor elements in coal: U.S. Dept. Interior, 1972b.

Minor elements in power plant ash: U.S. Dept. Interior, $1972 b$.

Powder River Basin

Energy resources map: Keefer and Schmidt, 1973.

Stripping coal deposits: U.S. Geol. Survey, 1974.

See also individual counties.

Sheridan County

Bar N Draw quadrangle: Mapel, 1974.

Coal drill-hole data: U.S. Geol. Survey and Montana

Bur. Mines and Geology, 1973.

Ranchester quadrangle: Barnum, 1974.

Stripping coal deposits: U.S. Geol. Survey, 1974.

Sweetwater County

Erickson-Kent Ranch quadrangle: Roehler, 1973a.

Four J Rim quadrangle: Roehler, 1972b.

Potter Mountain quadrangle: Roehler, 1973b.

Red Creek Ranch quadrangle: Roehler, 1972a.

Titsworth Gap quadrangle: Roehler, 1973c.

Teton County

Jackson quadrangle: Love and Albee, 1972.

Observation Peak quadrangle: Albee, 1972.

Rendezvous Peak quadrangle: Schroeder, 1972.

Two Ocean Lake quadrangle: Love, 1973. 